\title{
EU CONSTITUTIONAL LAW-POLICY MAKING AND THE NOTION OF "COMMON EUROPEAN LEGAL TRADITION"
}

\author{
A ELABORAÇÃO DO DIREITO CONSTITUCIONAL EUROPEU E A NOÇÃO DE \\ "TRADIÇÃO LEGAL EUROPEIA COMUM"
}

\section{LA ELABORACIÓN DEL DERECHO CONSTITUCIONAL EUROPEO Y LA NOCIÓN DE "TRADICIÓN LEGAL EUROPEA COMÚN"}

\author{
L'ÉLABORATION DU DROIT CONSTITUTIONNEL EUROPÉENN ET LA NOTION DE \\ «TRADITION LÉGALE EUROPÉENNE COMMUNE »
}

\author{
DOI: $\underline{10.5533 / 1984-2503-20113208}$
}

Vittorio Olgiati

\begin{abstract}
Leafing through a variety of EU official documents, it becomes apparent that, among the communicative strategies officially enunciated to support EU processes and policies, a special relevance has been ascribed to the notion of a "common European legal tradition." Indeed, reference to a "shared" and "settled" social, institutional and cultural context has been conceived of as a refined way to provide validity, legitimacy and social appeal to a quite recent geopolitical governance system such as that of European unionism. It is a fact, however, that, in spite of the authoritativeness of EU official statements, an important debate continues at the scientific level about the actual existence and/or consistency of such a "common legal tradition," due to either diverging historical socio-legal developments in the various EU member states or the novelty of EU legal constructionism. The aim of this paper is to deal precisely with this issue by focusing on the way in which an extraordinarily (explicitly and implicitly) selective mixture of old and new legal tools has been applied in order to portray the EU as an historically settled constituency. Accordingly, the most important EU normative steps towards EU constitutionalisation will be discussed and critically compared to previous - modern, pre-modern and ancient - European constitutional experiences.

Keywords: Common European legal tradition; EU constitutional process and policy; Modern and Ancient European constitutional models.
\end{abstract}

\section{RESUMO}

Caso forem analisados numerosos documentos oficiais da União Europeia, constatar-seá, em meio às estratégias adotadas para sustentar as políticas e o processo europeus, o primado da noção de "tradição legal europeia comum". Com efeito, a referência a um contexto social, institucional e cultural "partilhado" e "ancorado" representa uma sutil maneira de pretender validar, legitimar e defender a necessidade social de um sistema de 
governança geopolítica que, na melhor das hipóteses, podemos qualificar como recente, como é o caso da União Europeia. Não obstante a autoridade das decisões oficiais da UE, existe um amplo debate na esfera científica no tocante à existência e/ou à consistência de uma tal "tradição legal comum", tanto em razão de históricos desenvolvimentos sociais e jurídicos divergentes, quanto em função do caráter relativamente recente de uma legislação própria à UE. O objetivo deste artigo reside em tratar esse tema concentrando a nossa atenção no modo através do qual foi notoriamente associado um conjunto de novas e antigas ferramentas legais, visando-se justificar a existência da UE enquanto jurisdição historicamente coerente. Com este propósito, as mais significativas referências normativas da UE serão, no que diz respeito à sua constitucionalização, discutidas e confrontadas de modo crítico com as experiências constitucionais europeias precedentes (modernas, pré-modernas e antigas)

Palavras-chave: tradição legal europeia comum; políticas e processos constitucionais europeus; modelos constitucionais europeus modernos e antigos.

\section{RESUMEN}

En caso de que sean analizados numerosos documentos legales de la Unión Europea, se constatará, en medio a las estrategias adoptadas para sostener las políticas y el proceso europeos, el primado de la noción de "tradición legal común". En efecto, la referencia a un contexto social, institucional y cultural "compartido" y "basado" representa una sutil manera de pretender validar, legitimar y defender la necesidad social de un sistema de gobernanza geopolítica que, en la mejor de las hipótesis, podemos calificar como reciente, como es el caso de la Unión Europea. No obstante la autoridad de las decisiones oficiales de la UE, hay un amplio debate en la esfera científica en lo que tange a la existencia y/o a la consciencia de una tal "tradición legal común", tanto en la razón de la divergencias socio-legales históricas, como en función del carácter relativamente reciente de una legislación propia a la UE. El objetivo de este artículo reside en tratar ese tema focalizando en el modo por el cual fue notoriamente asociado un conjunto de nuevas y antiguas herramientas legales, visándose justificar la existencia de la UE en cuanto jurisdicción históricamente coherente. Con este propósito, las más significativas referencias normativas de la UE serán, en lo que dice respecto a su constitucionalización, discutidas y confrontadas de modo crítico con las experiencias constitucionales europeas precedentes (modernas, pre modernas y antiguas).

Palabras-clave: tradición legal europea común, políticas y procesos constitucionales europeos, modelos constitucionales europeos modernos y antiguos.

\section{RÉSUMÉ}

Si l'on analyse nombre de documents officiels de l'Union européenne, l'on constate, parmi les stratégies mises en place pour soutenir les politiques et le processus européens, la primauté de la notion de «tradition légale européenne commune ». En effet, la référence à un contexte social, institutionnel et culturel «partagé » et «ancré » représente une manière subtile de prétendre à la validité, à la légitimité et à la nécessité sociale d'un système de gouvernance géopolitique pour le moins récent, comme c'est le cas de l'Union européenne. En dépit de l'autorité des décisions officielles de l'UE, il existe au niveau scientifique un ample débat autour de l'existence et/ou de la consistance d'une telle "tradition légale commune », aussi bien en raison de divergences socio-légales historiques qu'en fonction de la relative nouveauté d'une législation propre à l'UE. Le but de cet article est de traiter ce thème en concentrant notre attention sur la façon dont ont 
été manifestement assortis un ensemble de nouveaux et d'anciens outils légaux pour justifier l'existence de l'UE en tant que juridiction historiquement cohérente. À cette fin, les jalons normatifs les plus significatifs de l'UE en vue de sa constitutionnalisation seront discutés et confrontés de façon critique aux expériences constitutionnelles européennes précédentes (modernes, pré-modernes et anciennes)

Mots-clés : tradition légale européenne commune ; politiques et processus constitutionnels européens ; modèles constitutionnels européens modernes et anciens

\section{1- The problem of EU institutional geo-political legitimacy after the Maastricht Treaty}

Leafing through a variety of EU official documents, as well as academic and mass media publications, it becomes apparent that among he communicative strategies that have been officially enunciated in over the past few decades in order to defend the idea of the EU governance system as a geopolitical entity with a constitutional nature, one of the most relevant, in political, ideological and normative terms, is that related to the attempt to provide an account of the origins and development of this EU governmental system as a process and policy not only fostered by a "common destiny," based on "common interests," but also by shared social experiences, based on a "common European legal tradition." Such a legal tradition, stemming from a common cultural heritage, is currently epitomised by the EU notion of acquis communautaire. Yet, it is actually derived both from modern enlightened ideals, institutions and values, which have themselves been flourishing since pre-modern times, and from ancient practices and doctrines, nurtured by the thousandyear-old European socio-institutional civilisation.

Even when viewed superficially, there is hardly any doubt that the emphasis put on the existence of a "common European legal tradition" has been seen as central for establishing the validity and legitimacy of the entire evolutionary strategy of the European Union as an historically irreversible fait accompli: i.e., as an already well-rooted geopolitical governance model of continental dimensions, based on a visible, enduring and (possibly) autonomous constitutional history.

A reference to a "settled" normative order and a "shared" socio-cultural context rooted in clearly recognizable civilisation patterns is undoubtedly a refined way to technically define (and make socially appealing) the mutual relation between social embedding and institutional connectedness of common values and interests within the EU, the EU member states and the European society as a whole. After all, how can one 
undervalue the pivotal role that a space-time nexus can play when instrumentally used as a veritable symbolic and material socio-legal device ${ }^{1}$ ?

It is a fact, however, that, the so-far significant lifespan of the EU process and policy notwithstanding and in spite of the authoritativeness of official EU sources, an important debate continues at the scientific level about the actual existence and/or consistency of such an EU "common European legal tradition," due to either contradictory developmental paths of past institutional arrangements or the novelty of the EU legal policy making.

Surely a discussion about whether there exists a common European legal tradition continues to be an important cultural-political issue as regards the prospective advancement of European unionism. The present study can easily be situated within this sort of scientific debate. However, its aim is neither to solve nor to exacerbate the controversy, but, rather, to focus on how and why an extraordinarily (explicitly and implicitly) selective mixture of a variety of old and new legal materials, each drawn from an equally extraordinary range of ancient and modern legal sources, has been the leading rationale of the overall EU socio-legal design. Since the fieldwork and the topic are quite complex, both in theory and in practice, the discussion will be carried out by focusing on what is surely the most emblematic outcome of such EU experimentum juris so farthe emergence of a sort of EU constitutional doctrine.

Besides the above, however, another (albeit implicit) aim will characterize the discussion. As we know, the way in which the EU constitutionalisation proceedings have actually been y carried out (from 1990 to 2000) and, subsequently (from 2000 to 2008), the way in which they have been formalized by means of the drafting of veritable "Constitutional Treaties," have both been far from socially and politically uncontroversial. This has been soto such a degree that,in spite of the amount of promotional efforts, the entire EU constitutional project has turned out as a remarkable failure, as has been demonstrated bythe rejection of those Treaties, when subjected to evaluation by EU citizens over the course of a series of national referendums. In this respect, the subsequent approval of a third Treaty, - a mere re-drafting of the rejected, abovementioned, "Constitutional Treaties", less emphatically labelled as the "Treaty on the Functioning of EU Institutions", otherwise known now as the "Lisbon Treaty," did not change at all the hostile, negative, "social climate" epitomised by the political responses to

1

Olgiati V. (2005 a). "Spazio e diritto. La dimensione spaziale del diritto e la costruzione giuridica dello spazio", Studi Urbinati, Scienze Umane e Sociali, B, anno LXXXV , Quattroventi ed., Urbino, p. 335352 . 
the above mentioned referendums. Indeed, it is possible to state that the enforcement of the Lisbon Treaty certified not only the existence of radically different visions and expectations as regards EU governance among EU citizens, but also the rise of serious additional legal and political problems among EU member states as regards their relation with the EU governance functioning as such, actually now implying a veritable multilevel, asymmetrical, constitutional model.

This being so, the discussion that follows can also be interpreted as an attempt to make apparent an issue that has been often hidden or ignored, but that is now coming to the fore: the correlation between (i) the ideological premises according to which the EU constitutional design has been officially enforced, (ii) the explicit instrumentalism about the use of the variety of legal sources that have been put forward to provide the EU Treaties with plausible legitimacy, and (iii) current rising dismay, if not reaction and opposition, regarding the actual social, political and institutional implications of EU constitutional legalpolicy making as such.

\section{2- The constructivist legal revisionism of the EU constitutional design}

A technical look at the text of the first - failed - EU Constitutional Treaty provides an enlightening entry point for discussing what has been said above. Even at first glance, it is apparent that the text of the EU Constitutional Treaty embodied the quintessence of EU law and policy making as it has been developing since the Single European Act took effect in 1984: a mixture of voluntaristic-rationalistic legal constructivism and jusnaturalistic-decisionist neo-institutionalism, both developed according to two (theoretically divergent) age-old principles: necessitas jus constituit and auctoritas, non veritas, facit legem.

As a constructivist regulatory model, the text of the above-mentioned Treaty is surely a sort of creative/regressive re-issue (with late-modern overtones) of Rousseau's "social contract." Motivated by a veritable status necessitatis, it is the result of a contractual agreement between EU member states acting as private agents, intentionally disposed to limit their own sovereignty so that it can be implemented (by virtue of the newly-created EU legal principles of "direct effect" and "supremacy") by EU agents (devoid of a substantial democratic legitimisation) as if it expresses the general will (of European society) in view of the pacific cooperation of each (State) and all (citizens), and 
therefore in the general interest of Europe as a whole, as formally constituted by the Union.

As one can see, in the articulation of its essential elements, the content of this EU Constitutional Treaty does not appear to diverge greatly - mutatis mutandis - from that hypothesized by Rousseau to explain the shift from a "state of nature" to a "civil society" The only exceptions - intriguing and innovative - are that (1) the agents, instead of being physical persons, are nation-states and EU organs (thus substantiating Wolf's and Pufendorf's absolutist theorizing, according to which political institutions are social actors acting as individual subjects), (2) there is no original "state of nature" except that given by the political and legal systems of the current European pouvoir constituées, just as (3) there is no civil and political society except through the re-enforcement of the existing (politically and legally constituted) European power elites. The novelty of the Treaty's text, therefore, is that it is the result of a self-interactive process, an act of self-observation and self-recognition of mere vested interests and values, brought about and intentionally oriented to function in the absence of, an explicit, visible and substantial, popular pouvoir constituant.

The above being the case, the legal intent of the Treaty as a whole is, therefore, clear: to bring things into being solely by means of words - as authors as varied as Hagestrom and Dworkin would say - by means of the everlasting constructivist $A / s O b$ (as if) legal technique ${ }^{2}$ : a technique typical of the Ratio Status before and after Machiavelli, and dating back to the old Roman Arcana Imperii legal tradition mentioned by Tacitus ${ }^{3}$.

In addition, as a neoinstitutional regulatory model, the Treaty is an equally interesting case of a creative/regressive re-issue (with late-modern overtones) of a wellknown constitutional trend leading to the constitutional hypostatisation of the judiciary as the "supreme power" of vested political constituencies. To - get a sense of this trend (and, consequently, of current political activism of the justice system at national level as well) it is sufficient to consider thatthe reference within the text of the Treaty to traditionally selfstyled universal values and principles, a practice typical of early Enlightenment and classical political economy narratives, overlaps with a late-modern constitutional architecture that, for historical reasons, is the outcome of the traumatic "bifurcation" of

\footnotetext{
2

Vaininger H. (1911). Die Philosophie des Als Ob, Berlin (Italian translation by F. Voltaggio (1967). La filosofia del "come se". Sistema delle finzioni scientifiche, etico-pratiche e religiose del genere umano, Roma: Ubaldini).

3 Olgiati V. (2003). "The EU Charter of Fundamental Rights. Text and Context to the Rise of a 'Public Interest' Eu-oriented European Lawyer”, International Journal of the Legal Profession, v. 9, n. 3, p. 235-250.
} 
Western European constitutionalism that occurred after the failure of the Weimar Republic and the rise of the Nazi regime: i.e., the "bifurcation" that became officially apparent, as an aftermath of World War II, as regards the newly-created Italian and French constitutional systems. In short, while Italy adopted the constitutional principle of "de-personification" (mainly, as a reaction to the rule of a single party ruled by a single man), France, by contrast, adopted the principle of a "commissarial presidency" (mainly, as a reaction to the rising complexity of their multiparty system) as regards the highest State authority and, therefore, State sovereignty.

Indeed, if one carefully reads the text of the Treaty, it is apparent that the emphasis placed on liberal-democratic values and principles as EU legal foundations recalls the Italian constitutional model that took effect in 1947, in which no real sovereign subject be it either a political leader, a particular class, a party, a king or the people - seems to hold the "supreme power", this being ascribed to, and epitomised by, the Law as the ultimate foundational value. On the other hand, the emphasis placed on the functioning of the EU institutions and decision-making procedures recalls, in turn, the French constitutional model that took effect in 1957, in which the State sovereignty is not vested in a legibus solutus leader, class, party, etc., but, instead, in an agent/agency provided in some way with relatively discretionary powers, in order to bypass the formal-legal design of the political dynamic of the State machinery. In short, the supreme power is embodied by a sort of powerful, politically independent, "commissioner" who is able to act in case of a recurrent (i.e., not exceptional, but routine) state of socio-political necessity 4 .

Taking the above into account, it is clear that the content of the first - failed - EU Constitutional Treaty aimed at promoting, an innovative, not at all traditional, social, legal and political order, as demonstrated by the fact that it somehow "neutralised" the abovementioned "bifurcation" - while up-dating its historically-determined rationale - by including and combining, simultaneously, the newly-created Charter of Fundamental Rights, as defined by the European Court of Justice (see par. 4), and a variety of commissarial structures vested with discretionary autocratic powers.

Why has all of the above been done in such a convoluted, explicit/implicit way?

The most credible reason is that there is no legal system in which the theory and practice of the Constitution do not, in one way or another, refer back to the historic

4 (2005 b). "The Eastern Europan Enlargement and the Janus-headed Nature of the Constitutional Treaty", In W. Sadurski; A.Czarnota; M. Krygier (eds.). Spreading Democracy and the Rule of 
experience of nation-state nationalism, an inheritance which the European Union clearly tends to reject and surpass ${ }^{5}$.

Indeed, the problem of the theoretical and practical connection/detachment of EU governance vis-a-vis nation-state constitutional models is rather serious. This is because (1) the EU is not and does not exist as a nation-state, having come into existence as the result of the application of international treaties; consequently (2) it does not have the possibility of setting up its own democratic-representative constitutional system, rooted, as in the case of the nation-state, in the principle of legality and on the criterion of the fiduciary mandate, lacking as it does any exclusive sovereignty over its own people or its own territory. In other words, not only is it the case that the process of European constitutionalisation cannot give rise to a constitutional order similar to any modern nationstate model, but, in the event of such a process being completed by following, in one way or another, the historic pattern, or the essential guidelines, of the nation-state, the EU would undermine the historic tradition of western constitutionalism itself, thereby openly putting into question the monopoly of the existing constitutions produced and enforced by the EU-member states ${ }^{6}$.

Given the above, it is easy to understand the caution with which EU constitutionalisation has been undertaken and the subsequent difficulties within its development. But for the same reason, it is also easy to understand why EU governance run by minority factions of national power elites, confronted with a weak democratic consensus and provided with quite inorganic structures - requires the official support of assertions such as that about the actual existence of a "common European legal tradition" in order to reinforce the legitimacy of the EU process and policy as a veritable geopolitical self-fulfilled "prophecy".

\section{3- The ideological content of the Preamble of the failed first "Constitution for Europe" Treaty}

While the content of the first EU Constitutional Treaty - labelled explicitly "Constitution for Europe" - aimed at creating an up-to-date EU constitutional governance

\footnotetext{
Law ? Implications of EU Enlargement for the Rule of Law, Democracy and Constitutionalism in PostCommunist Legal Orders, Springer Scientific, p. 27-49.

$5 \quad$ Habermas J. (1988). Die postnationale Konstellation, Frankfurt-am-Main: Suhrkamp.

6 Fioravanti M., Mannoni S. (2001). "Il 'modello costituzionale' europeo: tradizioni e prospettive”, In G. Bonacchi. Una Costituzione senza Stato, Bolgna: II Mulino, p. 23-70.
} 
system by "rescuing" and combining a variety of ancient and new legal tools, the Preamble of the Treaty shows an additional rationale: to distract attention, by means of an idealistic narrative, from major ideological gaps and contradictions occurring within contemporary European constitutional experiences.

As a matter of fact, the early text of the Constitutional Treaty Preamble solemnly recalled a statement of an ancient Greek historian, Thucydides, in order to stress the eternal "civilisational mission" of Europe in the world and its still living attachment to everlasting humanistic values and principles, such as those now formally recognized under the label of the inviolable rights of the subject and respect for the law.

No mention was made, by contrast, of, e.g., the so-called "Manifesto di Ventotene," written in the Ventotene prison, during the reign of Fascism, by one of the leading Italian promoters of European unionism, Altiero Spinelli. In that Manifesto, the ideal of a united Europe is conceived of as the only way to overcome - verbatim - the "civilisational crisis" of continental European societies: i.e., the rupture of the Western Weltanshauung, and the turn towards extreme forms of authoritarianism and totalitarianism. In other words, the EU Preamble not only ignores what was - and still is - the core mission of the EU project, i.e., to overcome domestic and exterior conflicts, but also hides the fact that the founding fathers had called for a veritable "civilisational transition" from what might be called modern Western legal barbarism, i.e., nothing less than a substantial "transition from within."

Besides, no mention is made in the Preamble about other, subsequent, constitutional "transitions," such as those that have occurred in Greece, Portugal and Spain, on the one hand, and in East Germany firstly and then in all Eastern European countries of the so-called Soviet Bloc, on the other hand. Even less mention is made of European countries' "transitions" from colonialism, i.e., about the ways in which e.g., Belgium, England and France have opposed the claims for Western-styled national independence, civil rights and self-determination made by Asian and African colonized countries. Last, but not least, those who drafted the Preamble simply "forgot" that for about 40 years this European unionism has grown up in a state of "limited sovereignty," since its member states have had to comply, in one way or another, with the overwhelming military and financial rule of the Pax Americana.

In brief, the Preamble has been idealistically constructed as a sort of ideological "prologue," as has been common among legal preambles since the Code of Hammurabi. However, this has been done so as to avoid any historically determined account of a very 
basic contemporary legal issue: "to reckon with the past" on the part of the entire European society (Western and Eastern, modern and contemporary ) vis-à-vis either itself or various worldwide phenomena (colonialism, religious wars, dictatorships, etc.). In this respect, one could argue that, for opportunistic reasons, those who drafted it opted for a veritable legal amnesic-amnesty, as suggested by a venerable European legal tradition dating back to the end of the Peloponnesian War between Athens and Sparta in early $14^{\text {th }}$ century B.C. ${ }^{7}$ However, if this is so, it has been done in a completely new way, because the concern of the Preamble is merely one-dimensional, being oriented towards EU selfreferential interests. It lacks, therefore, any logic of reciprocity, which, by definition, is the basic rationale for any "peaceful" political settlement.

This evidence, in turn, makes apparent another issue, i.e., the absence of any reference to the so-called "intelligence failures" and "false promises", of (western-styled) modernity. As a number of "promises" that are at the core of the Preamble have been at the core of Enlightenment and classical political economy narratives as well, this absence cannot be undervalued: it signals that the Preamble ideologically repressed and politically avoided a scientifically plausible and socially adequate representation of what current and prospective European socio-legal dynamics is and could be like. Indeed, how can one ignore that the Enlightenment's claims for a "progressive" human/social future turned out "dialectical" in the course of the $20^{\text {th }}$ century ${ }^{8}$ and that old and new theories of economic liberalism are not at all unconnected with what,generally speaking,is nowadays called "the risk society"?

\section{4- The "Nice Charter" as a political "manifesto" of EU constitutionalism}

What has been said so far opens a window, but does not cover the whole spectrum of our concern.

Another piece of the first - failed - EU Constitutional Treaty deserves a special comment here: the EU "Charter of Human Rights and Fundamental Freedoms", otherwise known as the "Nice Charter," or the Nice Treaty, which took effect in 2000.

Unlike classic historical charters such as the Magna Carta or the Universal Declaration of Human Rights, the EU Nice Charter does not mark the emergence of a new model of socio-political coexistence or a new form of government: it merely outlines a 
network of general legal standards useful for "smoothly" improving the governance (i.e., the techno-structural functioning) of EU institutions and its legitimacy in terms of socialideological acceptance. This, however, is done in an extraordinarily innovative way.

For this purpose, in fact, the Charter established an absolutely new legal framework based on the ontological equalisation of a variety of human rights and fundamental freedoms that the European Court of Justice created ex novo or originally "borrowed" from national legal systems and then established as a constitutive part of the so-called acquis communautaire. Such equalisation has been made possible by virtue of the development of a new legal principle: that of the axiological indivisibility of such a variety of rights and freedoms as fundamental legal pillars of the whole EU legal order. As a result, the Charter now contains - and must enforce as indivisibly equal - rights and freedoms that had already been theorised, produced and/or recognized, despite the fact that the original theorization, etc., had been done within the context of different spacio-temporal conditions, according to different interests and values, within different legal systems, and by different social forces. This means that, e.g., the enforcement of a fundamental right such as "human solidarity" cannot be theoretically and practically detachable from the enforcement of fundamental freedoms such as "economic competition," and vice-versa, each having the same legal validity and efficacy within the EU ${ }^{9}$.

Interestingly, the legal device developed so as to avoid any legal contradiction about the above mentioned equalisation is, in turn, based on an equally extraordinary new criterion: the insertion of (a) techno-scientific achievements, (b) economic activity and (c) individual/social creativity as veritable formal-official legal sources of legal cognition and interpretation for any sort of EU legal decision making.

Unfortunately, it is not possible to discuss the above technical solutions in detail. One issue, however, deserves to be highlighted: while economic freedoms gain an equal position vis-à-vis human rights, nothing compensates for the fact that, in early the $20^{\text {th }}$ century, human rights lost any universal and/or human character strictu sensu as soon as they were formally codified (since the space-time contingency of positive law makes them (1) changeable at whim or by force, (2) subject to discretionary interpretations, and (3) susceptible to occasional power games). At the time of the Weimar Constitution, the notion of "fundamental" rights was thus suggested not only to cover such a semantic and 
operational desempowerment, but also to create a totally different institutional system. Actually, since then, the term "human/fundamental rights" no longer expresses the individual freedoms of personhood, but, rather, the kind of political-institutional ordering principles of the given system that enforces them ${ }^{10}$. Accordingly, what, e.g., the Nice Treaty still labels as human rights can only be conceived of as either rules for protecting the EU institutional agents (EU member states in particular), or as legal provisions sustaining the constituencies in which the EU vested power in the first place, rather than as a direct guarantee of the rights of individual subjects.

A similar paradigmatic shift occurred in the notion of "democracy" as well. If one reads any official EU legal document, the term "democracy" merely means official acts and procedures performed by certain (more or less representative) agents according to certain (more or less consensually shared) standard rules. This did not occur by chance. Since the early $20^{\text {th }}$ century, the legal positivisation of the concept of democracy implied a revision of the traditional notion of "rule-of law" as well. Commonly epitomized as the quintessence of a truly democratic legal system, the notion of "rule of law" had been forged in the second half of the $19^{\text {th }}$ century by liberal ideologues to express democratic ideals. ${ }^{11}$ By the $20^{\text {th }}$ century, it had lost its formal-abstract universal character, having become either an indicator of or synonymous with the so-called Administrative State. Finally, it took on the meaning within official law of a mere binding procedure.

As if the above were not enough, even the theory and practice of official law as a procedural system of a technical nature underwent a substantial revision. Notwithstanding the most refined doctrinal efforts made over the past 50 years, the current procedural model does not fit at all with classical political economy and Enlightenment standards, for socio-political values and interests can no longer be theoretically referred to, or practically embodied by, a "common" rational actor pursuing "rational" choices. To bypass the limits of the above-mentioned traditional theorising without questioning its original logical core, two completely new arrangements have been adopted: (a) the establishment of the socalled "collegial formations", i.e., groups of qualified agents semi-autonomously acting as technical experts with the procedural know-how required for performing a given type of lawmaking, and (b) the enforcement of selective networks of qualitative procedural

10 Gozzi G. (1999). Democrazia e diritti. Germania: dallo Stato di diritto alla democrazia costituzionale, Bari: Laterza; Pombeni P. (2000). "Dal liberalismo al liberalismo? Itinerari della costituzione europea”, In L.Ornaghi L. (ed.). La nuova età delle costituzioni, Bologna: Il Mulino, p. 23-47.

Fioravanti and Mannoni (2001). Op. Cit. 
requisites, i.e., a sort of uniform body of legal standards, so as to provide a procedural threshold for legal cognition and interpretation ${ }^{12}$.

Needless to say, typical examples of these two arrangements are limited to either the EU commissions and the European Court of Justice or the list of fundamental rights and liberties set up by the same Court and now included in the Nice Charter.

In this respect, the fact that the EU equipped itself preliminarily with a charter of fundamental rights and freedoms, and only afterwards with a legal text properly called a "Constitutional Treaty", and not the other way around, is anything but a marginal fact ${ }^{13}$. It is a direct consequence of the above-mentioned "bifurcation" that occurred after the failure of the Weimar Constitution (supra, par. 2) and the management of it within a unique body (i.e. the judiciary) as the best way to avoid open constitutional conflicts. Henceforth, it is not surprising that although the Nice Charter had originally been set up as a veritable political document, it has actually been conceived of and drafted (since its first draft) as if it were a legal text ${ }^{14}$ so that it could easily be used by the European Court of Justice in this sense. In turn, this use perfectly fit the overall EU goal of Strukturbildung. This is shown by the fact that the EJC has, since the enactment of the Nice Charter, devoted its jurisprudential activity to the enhancement a sort of EU constitutionalisation, either by mixing existing common law and civil law rules or by developing a totally new legal approach. The strategy has been made possible by art. 220 of the Treaty of the European Community, which obliges the Court (solely) to "enforce the law." Given the absence of a system of strict legality over the past 40 years, the Court has, therefore, had the opportunity (1) to treat certain values and rights as if they were sources of community law, (2) to declare these values and rights as fundamental for EU governance, and, (3) to exploit their ex post formal recognition in subsequent EU Treaties as if they were, indeed, already part of what it labelled aquis communautaire ${ }^{15}$.

12 Sciulli D. (1988). "Towards a Societal Constitutionalism: Principles of Communicative Action and Procedural Legality", British Journal of Sociology, 39, p. 377-407.

13 Fioravanti M. (2000). "Costituzione e politica: bilancio di fine secolo”, In L. Ornaghi (ed.), La nuova età delle costituzioni, Bologna: II Mulino, p. 49-67; Tridimas T. (1991). "Judicial Review and Community Judicature: Towards a new European Constitutionalism?", Turku Law Review, 3, 1, p. 119-129.

14 Paciotti E. (2001). "La carta dei diritti fondamentali: una novità istituzionale", In G. Bonacchi (a cura di). Una costituzione senza Stato, Bologna: II Mulino.

15 Helander, P. (2001). "Supremacy and Scope of Community Law: Room for Principles?" Turku Law Review, 3, 1, p. 43-58; Jyranki A. (2001). "Fundamental Rights and Community Law: Concern for the Rights of Man or Power Game of Institutions", Turku Law Review, 3, 1, p. 59-70. 
As one can see from the above, the role of the European Court of Justice in shaping the Nice Charter, and therefore the basic framework of the Constitutional Treaty, has been absolutely pivotal. The result so far, however, is far from having actualised the claim that the acquis communautaire is the manifest expression of a proper legal "tradition." As we know, a legal tradition - like any tradition - requires, by definition, a congruous period of spatial and temporal consolidation in order to be considered as such. Such a legal tradition, which could serve to foster significant socio-legal changes, cannot simply be brought into being by using lawmaking in constructivist terms. Accordingly, in order to better understand how and why the constitutional EU experimentum juris has been carried out, we must enlarge our analytical perspective and focus on the legacy of earlier legal developments that opened the way to European unionism.

Before moving on to discuss such early legal developments, however, an analytical account must be provided for the most recently approved law expressing EU constitutional constructivism,: the so-called "Lisbon Treaty."

\section{5 - The "Lisbon Treaty": a move ahead or a retreat from EU constitutional project ?}

After the rejection of the first and second EU "Constitutional Treaties" by popular referendums, the only way left to pursue the task was to bypass European citizens' direct involvement in the matter. This is the case with respect to the EU direct enforcement of the EU "Treaty on the Functioning of the EU Institutions," otherwise known as the "Lisbon Treaty," because it was originally signed in Lisbon in December of 2007. As such, indeed, it has officially been heralded as an additional step in the advancement of EU constitutionalisation.

From a formal viewpoint, the political aim, the text and the spirit of this Treaty do not greatly differ from those of the previous ones. Speaking at the European Parliament on July 23, 2007, Valery Giscard D’Estaing said, verbatim “En termes de contenu, les propositions demeurent largement inchangées, ells sont justes présentées de façon differente.... Les gouvernements européens se sont ainsi mis d'accord sur des changements cosmetiques à la constitution pour qu'elle soit plus facile à valer." (In terms of content, the propositions remain largely unchanged. They are just presented differently ... The European governments have thus agreed on cosmetic changes to the constitution because they are easier to appreciate.) From a substantial perspective, by contrast, it is apparent that the top-down EU constitutional strategy has not only been reiterated, but 
also empowered - at least on paper - by establishing what we could refer to as "structuralfunctional couplings" between and within the two most relevant EU issues at stake: EU institutional governancet and EU socio-economic promotion.

As far as EU governance is concerned, the Treaty combines both the normative and institutional "acquis communaitaire" achieved since the Rome Treaty (EEC) and the Maastricht Treaty (EU). More precisely, it (i) abolishes the EEC as a separate legal entity, by merging it with the EU, and (ii) detaches the Charter of Human Rights and Fundamental Freedoms from the political content of the Nice Treaty, recognizing the former as a proper legal entity. In summary, the Lisbon Treaty officially establishes the EU as unique political and legal - governance system, enabling it to act as a quasi-sovereign institution with respect to external relations and providing it with exclusive competence (vis-à-vis EU member states) in a number of relevant internal areas. The expected outcome is the empowerment of EU governance, legally and politically, in both continental and global respects.

As far as the EU internal socio-economic promotion is concerned, it is worth mentioning the recognition of the principle of "reinforced cooperation" between most active EU members states; the possibility to establish "vanguard teams" to deal withsocial, institutional and economic issues; the emphasis put on "intergovernmental method" and "subsidiarity" in order to enhance public and private joint ventures. In summary, the "action-theory" that permeates the Lisbon Treaty favors the promotion of country-specific "converging advancements-through-emulative rivalries" as well as local context-based "paths for mutual learning-through-differential achievements" wherever and whenever possible. The expected outcome is the institutionalisation of a veritable intra-European competitive/cooperative "regionalism," characterised by the establishment of the most advanced forms of entrepreneurial public/private clusters, teams, networks, etc., each of which can, potentially, create

leading territorial "enclaves" of expertise, creativity and excellence, thanks to the pivotal spreading of all sorts of country-specific higher knowledge and know-how provided by the most gifted local areas and districts.

Although what has been mentioned above looks promising, substantial questions have continued to worry many observers: Will both EU governance institutions and EU member states' multiparty systems be politically ready to comply with the Lisbon Treaty provisions? What sort of endogenous and exogenous social, political and/or economic potentials and obstacles are at stake? Can regional dynamics overcome intra-continental 
differences? In summary: how can EU-enforced, top-down bureaucratic governance effictively synergise with the parallel EU quest for radical social, economic and cultural changes based on widespread asymmetric and asynchronous local activism?

An indirect, but substantial, answer to such questions was given just a year after the signing of the Lisbon Treaty, in 2008, by the spreading worldwide of the worst economic crisis since 1929. As a consequence, it has become apparent that the extent to which some European countries, have been affected by the crisis could jeopardize the entire EU strategy. This, in turn, has created a situation in which we are now witnessing a rising military and political fracture within and among the most powerful EU founding member states regarding how to deal with the geopolitical instability of the EU member states bordering the Mediterranean Sea. Consequently, voting results on a number of national ballot issues make apparent that an increasing number of European citizens explicitly support local claims for cultural and political separatism. This being so, it seems unlikely that the Lisbon Treaty provisions can be successfully implemented in the forthcoming years.

This last statement should not be shocking. To understand the failures that the EU constitutional process and project have endured, it is worth considering that the whole historical path of European unionism has always been characterised by a variety of geopolitical troubles. In this respect, a focus on the legal and political events before the European Economic Community was officially established in 1957 seems opportune.

\section{6- Early legal paths towards European unionism}

To provide an insight into the difficulties that European unionism has had to surmount since its early days, a significant starting point that deserves to be recalled here is the variety of legal doctrines and models that have been used by both European politicians and European intellectuals during the development of the notion of "European Union" from a mere ideal type to a potential institutional body. For this purpose, let us deal with the socio-political dynamic and the regulatory sphere respectively.

As regards the socio-institutional dynamic, the first important event in the earliest stage of European unionism is that the Congress of Europe - having organised the International Committee of Movements for European Unity (1946) and set up the agenda for the constitution of a European Assembly a Charter of Human Rights and a European Court, together with the European Convention for the Protection of Human Rights and 
Fundamental Freedoms (1950) - triggered the foundation of both the Council of Europe (1949) and the European Court of Human Rights (ECHR) (1951). While the Council was inspired by the federalist-pacifist doctrine, as elaborated at the end of the 1940s, the $E C H R$, on the contrary, was inspired by a doctrinal mix traceable to a universal enlightened idealism, which can be summarised by the formula "moderate neojusnaturalism imbued with positivism." In practice, federalism has, since that time, always been a quite minor issue for European official institutions, whereas the universality of human rights has been opposed - as has been previously stated - by treating these fundamental rights as merely equal in value to market freedoms in the Nice Charter. As regards pacifism - i.e., the rejection of war as a means to resolve conflicts - the politicalmilitary action enacted by EU member states, especially in the past few decades, in violation of domestic constitutional laws and international treaties, on the European continent itself (e.g., in Kosovo) as well as in various other parts of the world, is a fact which speaks for itself.

A second important obstacle for European unionism is that the origin of the current EU governance system is related to the failure to implement two organisations proposed between 1952 and 1954, a European Defence Community and a Political Community. The result was the political-military division of Europe into two "blocks" and the consequent economic-political-cultural subjection of European states to two different, conflicting, political-constitutional models. This division, which officially remained in force until 1989, nourished in the West a concept of the process of European unification (and of "liberal democracy") as an expression of the science of social organisation oriented towards a "welfare state", as opposed to the theory and practice of "state socialism" (and of "popular democracy"). The long-term socio-legal implications of such an ideological, political, economic and military clash over several decades, despite recent changes, cannot be said to have been totally overcome.

A third significant factor is that the Treaty of Rome (1957) set up neither the Defence Community nor the Political Community, but gave rise to the European Economic Community (EEC). In pursuing the Four (market) Freedoms, the EEC strongly opposed the federalist idea, promoting, instead, a constant oscillation between regionalism and centralisation. Besides, it never aspired to compete at a higher level with the principle of sovereignty of the nation-state, whereas the European Court of Justice has systematically attempted to do so since its establishment (1960). In fact, thanks to the well-known ECJ's "praetorian law," increasingly incorporated as a reference source in the subsequent 
treaties, from the Maastricht Treaty onwards, the general political configuration of the EEC had radically changed before the latter was merged with the newly created EU in 2007 .

A fourth important factor is not so much the attempt to integrate EU institutions and European society by virtue of general elections by suffrage of a European Parliamentary Assembly (1979), but, rather, the geopolitical mix between recurrent "territorial enlargements" and "security arrangements," in order to create the so-called "single European legal space." This, in turn, led to the development of a mix of decentralisation (diversity) and centralisation (supremacy) as aims of European governance, especially in those countries which not only had different features and different degrees of socioeconomic development, but which had no part at all in the evolution of the so-called EU acquis communautaire. Last, but not least, if one then considers that after the fall of the Berlin Wall all Eastern European countries (save Eastern Germany) were subjected to a systematic scrutiny - the so-called "EU parameters" - in order to be entitled to entry into the EU, while previous EEC enlargements had involved no such scrutiny, one can easily realise that a number of political-institutional questions arose about the inconsistency between the subsequent EU move towards EU constitutionalisation and the persistence of the so-called EU "democratic deficit."

As we can clearly see, even from this schematic summary, the 60-year development, since 1950, of European institutions can hardly be described as a theoretical-practical configuration of EU process and policy progressing along a linear path toward the establishment of a stable and coherent legal framework. Given this evidence, let us, therefore, turn our attention to the EU member states' pre-EU legal systems, i.e., to the historical normative models of the past, in order to try to find a plausible explanation for such a disquieting state of affairs.

\section{7- EU member states' $20^{\text {th }}$ century constitutional experiences}

While what has been mentioned above goes a long way toward explaining the sorts of problems faced by the EU today, it is not the whole story. The difficulties that European unionism has had to face can also be traced back to the fact that national models and doctrines of constitutionalism that have been influential in Europe over the past century correspond to such a variety of socio-political events that they can only be classified 
together to the extent that they refer to the general historic matrix of the nation-state ${ }^{16}$. Considering the $20^{\text {th }}$ century as a "short century," there is no doubt that the fundamental event is the Russian Revolution (1917). This set the stage for the emergence of a threeway split in the developmental path of the nation-state, towards three distinct political systems: "western" authoritarianism, "western" representative democracy, and "eastern" Soviet-style Communism. Within the period during which this split was in effect, which lasted up to the fall of the Berlin Wall (1989), we can then identify two distinct sub-periods: the sub-period between the two World Wars and that following the Second World War. Within both these sub-periods, each of the political systems featured distinct evolutionary patterns ${ }^{17}$.

To take just the "western" developmental path, the period between 1917 and 1945 is characterised in continental Europe by the progressive abandonment of so-called "State constitutionalism," based on the ordering function of the Civil Code and the domination of liberal ideology of the "rule of law," and on the progressive affirmation of the so-called "political constitutionalism," which settles conflicts among social interests by politicaladministrative means - so that the Constitution becomes, in Weberian terms, the emblem of social welfare and the nation-state recognises itselfas a "community of destiny."

In this respect, however, even the one-party models, such as those of Italy, German and Spain, are anything but similar: in Italy the "elasticity" of the Albertine Statute (i.e., the constitution of the Kingdom of Sardinia before the unification of Italy) was confirmed, concealing the tension between the dynastic set-up and the novi homines organised into the Fascist Party; in Germany the Nazi Party installed its own elitist order, which, rather than suppressing, overlaid the pre-existing constitutional system, thus giving rise to the socalled Double State; in Spain the Franco regime emerged from the clash between the monarchy and the republic, fused with the State-administration, and, unlike the other two regimes mentioned here, did not disappear at the end of the Second World War ${ }^{18}$. The English model, in turn, is anomalous, given the imperial structure and the common law system of the United Kingdom.

The period spanning between 1947 and the end of the century is marked by a type of constitutionalism centred on the concept of representative democracy, managed by coalitional multiparty systems, and on the constitutionalisation of basic social claims. This

$16 \quad$ Fioravanti and Mannoni (2001). Op. cit.

Pombeni (2000). Op. cit. 
model, however, has been informally replaced by a different format, which has hinged on the direct legal intervention of the State as an instrument of authoritative "mediation" between institutional values and economic interests. This, in turn, has opened the way to the so-called "political activism" of the judiciary, given the declining power of the representative democratic institutions as regards social conflict settlement ${ }^{19}$. In this case, too, significant national differences are apparent, due to (1) centralist, regionalist or federalist forms of governance; (2) republican or monarchic regimes, (3) types of procedures for determining the legitimacy of acts of constitutional relevance, (4) all operated through different legal systems, each of which is characterised by (5) countryspecific institutional, professional, conceptual, communicative, , arrangements.

As we can see, during this period in Europe's history, one ican hardly find a unitary tradition. Instead, one finds a plurality of normative systems, i.e., legal pluralism, as the dominant common European regulatory pattern.

If, however, one wishes to indicate common variables within such a legal pluralism, which were able to leave a deep mark within the nation-state models, and are still at work in the EU governance system, one cannot but outline at least: (a) the dialectical action of the theories of legal institutionalism, formalism and decisionism in shaping both formal and material constitutional dynamics ${ }^{20}$, and (b) the impossibility of a pacific conciliation of opposing principles, that is, the monarchic principle (legitimisation originating from blood descent) and the republican principle (legitimisation derived through pro-tempore election): an historic opposition that still acts as a basic rule among the European elite.

If, on the other hand, one wishes to identify the mark left by the EU legal policy making on EU member states' constitutional systems, one cannot fail to highlight the weakening of the ruling power of these systems, due to the erosion of national sovereignty, and the rise of large economic corporations, whether or not they are based near EU institutions, as veritable political and normative powers.

Last, but not least, two other variables need to be mentioned: on the one hand, the dismantling of Communist rule and the non-voluntary subsumption of its still living legacies onto the process of EU enlargement, and, on the other hand, the critical revision of both

\footnotetext{
18 Podgorecki A.; Olgiati V. (eds.). (1986). Totalitarian and Post-Totalitarian Law, Dartmouth, Aldershot.

$19 \quad$ Fioravanti (2000). Op. cit.

20 Mortati, C. (1998). La costituzione in senso materiale, Milano: Giuffré.
} 
liberal-democratic and of socialist constitutional models in relation to the "failed promises" - that is, the unsuccessful "potentials" - of both models.

In summary: over the course of the 20th century, the most apparent aspect of the common European legal tradition is surely that of the presence of recurrent forms and layers of legal pluralism, a fact that can hardly be hidden or ignored today, especially in light of claims about the alleged spreading of the so-called "global law," After all, how can one deny that legal pluralism in Europe is the other side of the coin of a deep-rooted, everlasting, European social pluralism? This being so, what about the rationale for such an historical legacy prior to the $20^{\text {th }}$ century?

\section{7- 19th century constitutional arrangements in Europe}

Looking backwards and focusing on $19^{\text {th }}$ century European legal systems, the only effective "common European legal tradition" that can be technically defined as such - i.e., within the general framework of a historically irrepressible socio-legal pluralism - is that related to the enforcement of the Ratio Status as constructed after Machiavelli, i.e., the well-known "Doctrine of the State Interests"21: a doctrine based on a widespread, systematic, hostility towards the principle of direct democracy.

This evidence should not be surprising: it is the most remarkable imprint of the absolutist state within the liberal-bourgeois nation-state, a mark which pervades, more or less implicitly, all $19^{\text {th }}$ century constitutionalism, from the Napoleonic Code to Jellineck's theorising, even though, in the period under consideration, the above items were articulated according to nationalistically-oriented models and school of thoughts, which, consequently, varied from one country to another.

As regards the models, it suffices here to mention the centrality of the parliamentary system in the United Kingdom, of the administrative system in Prussia and of the legislative system in France. In spite of their substantial differences, all these models had in common the attribution of mere ideological significance and a merely formal-abstract consistency to the "general will" of the people as a "constituent power."22

As regards the schools of thought, the "balance of power" doctrine deserves special mention. This involves the search for an equilibrium between the most powerful European

21 Meineke F. (1924). Die Idee der Staatrason in der Neueren Geschichte, Munchen-Berlin: Oldenbourg.

Fioravanti and Mannoni (2001). Op. cit. 
states, clearly a doctrine of Italian (Lorenzo de Medici) derivation, variously combined with, but more often opposed to, the "Jus Publicum Europaeum" doctrine, as originally theorised by Grotius. Although undoubtedly different from each other, these doctrines had nevertheless always had an implicit/explicit point in common: the assessment of the State's interests and Europe's "civilising mission" in the world based on the right of war, conquest, plunder and spoil ${ }^{23}$, i.e., these doctrines openly opposed a totally different "world order" model, namely that previously envisaged in the view of a worldwide peaceful interactive "communication" by the great jurist Francisco de Vitoria.

The $19^{\text {th }}$ century European legal systems were also influenced by an additional doctrine, that based on the vindication of human rights and of the right of resistance against any sort of constituted power, as epitomised in the rising opposition between theocratic absolutism and parliamentary constitutionalism. However, since the "rule of law" principle in Europe is by its very nature contrary to the democratic principle, ${ }^{24}$ we have to agree that both the republican irredentism and the libertarian universalism against the law of the $19^{\text {th }}$ century "universal monarchies" were no more than placed at a critical margin. This also holds true today, as individual freedoms and rights proclaimed by both American and French Revolutions became transformed from "human" and "universal" into formalabstract "extended privileges" under the rule of the Civil Code and - as we have already said - are now reduced to fundamental pillars of currently vested institutions ${ }^{25}$.

\section{8 - Pre-modern models of European constitutionalism: towards new normative scenarios}

Both the official EU claim about current actual existence of a "common European legal tradition" within the EU and the quite different, and much more complex, socio-legal scenario of such "commonality" provided in the course of the present discussion, are clearly due to the fact that, in the last instance, both hinge on the evolutionary itinerary of the constitutionalism of the $19^{\text {th }}$ and $20^{\text {th }}$ centuries, centred on the epochal rise, assessment and current crisis of the "nation-state" model. It is, consequently, easy to understand either the fear of some or the satisfaction of others about the fact that the process of European constitutionalisation - launched at the very moment in which the

$23 \quad$ Schmitt C. (1972). Le categorie del politico, (a cura di G. Miglio and P. Schiera), Bologna: II Mulino.

$24 \quad$ Fioravanti and Mannoni (2001). Op. cit.

25 Pombeni (2000). Op. cit. 
"crisis of the State" reaches an apical point at present - could promote a totally different, absolutely new, option: a veritable "Constitution without State."26

Interestingly, even if the above option is far from being at hand, scientific research is now seriously addressing - as it never had before - the problem of whether the concept of a "common European legal tradition," extraneous to the modern nation-state and leading to a truly unified legal order, can effectively be explicated. In this respect, therefore, two main interrogatives are at stake: (a) did any sort of constitutionalism ever exist before the advent of the modern nation-state and (b) could any sort of constitutionalism exist in the future without a nation-state?

If we think carefully, strange as it may appear, these two questions are by no means new.

At a theoretical level, we are well aware of the scepticism and ridicule which accompanied the affirmative response to both questions given, among others, by Saint Simon and Marx in the $19^{\text {th }}$ century, and by Kantorowicz and Gurtvich in the $20^{\text {th }}$ century, in almost prophetic terms. By now, it is at the level of historical-political reality that an affirmative response may be possible.

As has been noticed, the "explosion" of legal pluralism is an historic fact of such proportions nowadays that the centuries-old notion of the "constitution of the State" as based on a single normative power is considered almost inapplicable by some jurists and political scientists ${ }^{27}$. This leads to the growing promulgation of post-modern constitutional scenarios, not only by those hoping for a Kantian "perpetual peace" grounded on an universal law, but also by those emphasizing the social impact of the so-called "globalisation" up to the point of imagining the rise of a supranational, multidimensional and even fragmented, "Law Empire," driven by lex mercatoria ${ }^{28}$.

The above questions about Europe's future also lead to a growing theoreticalpractical interest in the distant past. This is because the sole historical periods in European history that can be exploited as real, historically-determined, frames of reference, that is, in which a European legal order of continental validity and legitimacy effectively existed, lie in the distant past. As one example, a significant contribution can be offered by the scientific appraisal of the political and legal legacy of the Carolingian Holy Roman Empire and of the 
subsequent Ottonian Renaissance (the residual structures of which, officially abrogated in 1806, actually remained in force in certain areas of Europe up to 1917).

Besides this line of enquiry, another significant, though in many ways quite different, contribution can be made by the critical study of the forms of non-state governments of the late mediaeval proto-capitalist economies - "the Phoenician-type empire" to use Braudel's expression - a veritable mosaic of rights and a surprising network of autonomous governance systems from which can be derived not only the separation between territorial status and political bonds - and, therefore, the concepts of "resistance", of "free will", of the dignity of the individual, etc. ${ }^{29}$, , but also the idea of the controlling role of corporations and familial communities, and, consequently, of the binding value of "civil" ties which were effectively reproductive because they were reciprocal.

Last, but by no means least, how can one forget the scientific renovation of the living legacy of the two civilisational models that shaped, before, during and after the constitutional experience of the Gothic rule, and that still acts, de facto, as a veritable legal "matrix" of a large part of contemporary European society, i.e., the universalistic nature of Christian and Islamic socio-legal orders?

Unfortunately, the discussion about these periods of European history cannot be expanded here. It should, in any case, be observed that the analogical reference to such ancient models of European "constitutionalism" poses serious problems of definition, not least that of the definition of the material and symbolic boundaries of the systems involved: territorial boundaries of sea and land as well as functional and existential boundaries of identity and belonging ${ }^{30}$. But these problems can also offer great possibilities for current EU constitutionalism as experimentum juris. After all, is it not, perhaps, true that the continual political and cultural rebalancing of ecosystemic and human relationships - by means of various exchanges - is among the most ancient and significant common experience of European political, social and legal systems over many thousands of years? $?^{31}$

28 Teubner G. (1997). "The Kings' Many Bodies: the Self-Destruction of Law's Hierarchy", Law and Society Review, v. 13, n.4, p. 763-787.

29 Szucs J. (1996). "The Three Historical Regions of Europe", In V. Gessner; A. Hoeland; C. Varga (eds.), European Legal Cultures, Aldershot: Dartmouth, p. 14-48.

$30 \quad$ Le Ridier J. (1995). Mitteleuropa, Bologna: II Mulino.

31 Chabod F. (1955). Storia dell'idea di Europa, Bari: Laterza . 


\section{9- Retrospective constitutional visions about a future Europe}

The still living legacy of ancient European socio-legal traditions offers us the chance to focus, in conclusion, on one last, -intriguing, approach towards our topic, the portrayal of current constitutional "visions" of Europe's future drawn from a retro-prospective viewpoint, a viewpoint based on the fact that - as De Jouvenel would put it psychologically and culturally, currently dominant ideal constitutional models of Europe have already been formulated as a result of present and past experiences ${ }^{32}$.

Even though ideologically raised by EU officials, claims about prospective European "common destiny," "civilising mission," "common legal tradition," etc., recall three distinct evolutionary paths: the one based on the age-old model of governance that Montesquieu, following Machiavelli, envisaged, i.e., that of the search not for a procedural uniformity, but for a possible political equilibrium among the variety of European values, constituencies, practices, etc.; the second based, by contrast, on the necessity of formal regulatory standards, due to the problems raised by either Voltaire or Burke, i.e., that due to the diversity of European values and constituencies, etc., any equilibrium is always unstable and conflicts inevitably occur; and the third suggested by both Leibniz and Rousseau, based on a mix of the above, i.e., that, due to irrepressible diversity of European systems, both a balanced dualism between top-down and bottom-up constituencies and directorial guarantees stemming from a superior confederate asset are needed.

If so, how can one miss that the EU Constitutional Treaty, by superimposing an additional order/structure on national constitutional systems, has revitalized, e.g., the myth/reality of the leading "civilising mission," "common destiny" and "common tradition" of Mitteleuropa: i.e. ,the myth/reality of a never-ending historical trend spanning from the Holy Roman Empire - as a legacy of ancient Rome - up to the "universal" Habsburg Empire? And how can one exclude the possibility that the goal of a formally "reinforced" cooperation could be a stepping stone to a renewed Holy Alliance of continental dimensions among EU power elites, a structure able to impede the occurrence, on a European scale, not only of another Auschwitz, but also of another Thermidor?

In any case, whichever way one looks at the matter, there is no doubt that the memory of Hapsburg's Felix Austria offers to some an appealing historical reference to promote a long-lasting EU constitutional system, for it could motivate - as Bagehot would 
say - a sentiment of reverence for the venerable symbolism evoked by a traditional form of power and authority in a geopolitical context ever since characterised by cultural and ethnic diversity.

Having said the above, however, it would be naïve to undervalue the limitations that are inherent in the Mitteleuropean model, and, more particularly, the socio-political risks stemming from any sort of clannish ties. As is well known, the historical weakness of both the Holy Roman and the Hapsburg empires' models - in spite of recurrent intermarriages between power elites - is that the dynamic of internal cultural, political and social diversity, causes recurrent instability and enlargements and contractions of formal-official borders. In this respect - as authors as varied as Ehrlich and Gumplowicz have warned - one can hardly speak of a "common" destiny, tradition, or civilising mission even within the Mitteleuropa. The good, old, highly refined, structures of the so-called Reichtspublizistik, and its related "Empire Patriotism," were not able to counteract the recurrent clamor for what Ratzel called Lebensraum, either in the form of the enforcement of the cuius lex, ejus rex or cuius regio, ejus religio rules, or in the form of the struggle for a Sonderweg to national irredentism, independence and self-determination ${ }^{33}$.

In this respect, a last - but by no means least - issue cannot be left aside at the very conclusion of this study: by virtue of reiterated territorial arrondismants, the EU governance system now spans over a territory larger than that which both Napoleon and Hitler had tried to conquer and rule by force. OK. Unfortunately, however, no mention at all can be found in EU official documents of an outer boundary or a deadline (in the original sense of the word according to which a prisoner is shot when crossing the line) as regards EU territorial, economic, political, etc., incrementalism, especially beyond commonly acknowledged, traditional limes of what is meant by "Europe"34 (Olgiati, $2005 \mathrm{~d}$ ). As there is no reference in such texts to a European normative domain as a Finis Terrae, the option for a new sort of European imperial policy - as history teaches - cannot therefore be reasonably excluded.

\section{Bibliographical references}

Bonacchi G. (ed.) (2001). Una Costituzione senza Stato, Bologna: II Mulino.

Chabod F. (1955). Storia dell'idea di Europa, Bari: Laterza. 
De Jouvenel B. (1964). L'art de la conjecture Monaco : Futuribles, Ed. du Rocher.

Fioravanti M. (2000). "Costituzione e politica: bilancio di fine secolo", In L. Ornaghi (ed.), La nuova età delle costituzioni, Bologna: Il Mulino, p. 49-67.

Fioravanti M., Mannoni S. (2001). "Il 'modello costituzionale' europeo: tradizioni e prospettive”, In G. Bonacchi. Una Costituzione senza Stato, Bolgna: II Mulino, p. 23-70.

Gozzi G. (1999). Democrazia e diritti. Germania: dallo Stato di diritto alla democrazia costituzionale, Bari: Laterza.

Habermas J. (1988). Die postnationale Konstellation, Frankfurt-am-Main: Suhrkamp.

Helander, P. (2001). "Supremacy and Scope of Community Law: Room for Principles?" Turku Law Review, 3, 1, p. 43-58.

Horkheimer, M.; Adorno T.W. (1966). Dialettica dell'Illuminismo, Torino: Einaudi Ed.

Jyranki A. (2001). "Fundamental Rights and Community Law: Concern for the Rights of Man or Power Game of Institutions", Turku Law Review, 3, 1, p. 59-70.

Le Ridier J. (1995). Mitteleuropa, Bologna: II Mulino.

Meineke F. (1924). Die Idee der Staatrason in der Neueren Geschichte, Munchen-Berlin: Oldenbourg.

Mortati, C. (1998). La costituzione in senso materiale, Milano: Giuffré.

Olgiati V. (2003). "The EU Charter of Fundamental Rights. Text and Context to the Rise of a 'Public Interest' Eu-oriented European Lawyer", International Journal of the Legal Profession, v. 9, n. 3, p. 235-250.

(2005 a). "Spazio e diritto. La dimensione spaziale del diritto e la costruzione giuridica dello spazio", Studi Urbinati, Scienze Umane e Sociali, B, anno LXXXV, Quattroventi ed., Urbino, p. 335-352.

(2005 b). "The Eastern Europan Enlargement and the Janus-headed Nature of the Constitutional Treaty", In W. Sadurski; A.Czarnota; M. Krygier (eds.). Spreading Democracy and the Rule of Law ? Implications of EU Enlargement for the Rule of Law, Democracy and Constitutionalism in Post-Communist Legal Orders, Springer Scientific, p. 27-49.

(2005 c). "L’Unione Europea verso una Costituzione virtuale ?" In V. Cotesta (a cura di), le identità mediterranee e la costituzione europea, v . 2, Rubettino, Soneria Mannelli, p. 75-102.

Olgiati V. (2005 d). "Arcana Imperii: i confini dello spazio giuridico europeo", In E. Dell'Agnese, E. Squarcina (a cura di), Europa. Vecchi confini e nuove frontiere, Torino: UTET Libri, p. 63-79. 
(2007). "The Preamble of the Treaty that Institutes a Constitution for Europe: A Question of Virtual Reality", In P. Cserne; I.H. Szilagyi; M. Konczol; M. Paksy; P. Takacs; S. Tattay (eds.). Theatrum legal Mundi. Symbola CS Varga Oblata, Societas Sancti Stephani, Domus Editoria S. Sedis Apostolicae, Bibliotheca luridica Libri Amicorum 24, Budapest, p. 321-337.

(2008). "Legal Fictions as Constitutional Sociotechnics: A Study on Eu Constructivist Legal Revisionism", In J. Langer (ed.) Forces Shaping the EU. Social Science Approaches to Understanding the European Union, Frankfurt-am-Main: Peter Lang $\mathrm{GmbH}$, p. 133-152.

(2009). "Potentials and Obstacles in the Promotion of higher Knowledge in the European Area: The Post-National Question of European Intellectuals", In J. Langer, J. Pavicic, N. Alfirevic (eds.), Knowledge Region: Alps-Adriatic Challenge, Vol. I, General Perspectives, Frankfurt-am-Main: Peter Lang Gmbh Publ., p. 35-57.

(2010 a). "Il Progetto politico alla ricerca di un equilibrio neo-gotico", In A. Cantaro (a cura di), II costituzionalismo asimmetrico dell'Unione. L'integrazione europea dopo il Trattato di Lisbona, Torino: Giappichelli, p. 260-274.

Ornaghi L. (2000). "Introduction”, In L. Ornaghi (ed.), Una Costituzione senza Stato, Bologna: II Mulino, p. 7-16.

Paciotti E. (2001). "La carta dei diritti fondamentali: una novità istituzionale", In G. Bonacchi (a cura di). Una costituzione senza Stato, Bologna: II Mulino.

Podgorecki A.; Olgiati V. (eds.). (1986). Totalitarian and Post-Totalitarian Law, Dartmouth, Aldershot.

Pombeni P. (2000). "Dal liberalismo al liberalismo? Itinerari della costituzione europea", In L.Ornaghi L. (ed.). La nuova età delle costituzioni, Bologna: II Mulino, p. 23-47.

Quartish H. (1995). Giustizia politica. Le amnistie nella storia, Milano: Giuffré.

Schmitt C. (1972). Le categorie del politico, (a cura di G. Miglio and P. Schiera), Bologna: II Mulino.

Sciulli D. (1988). "Towards a Societal Constitutionalism: Principles of Communicative Action and Procedural Legality", British Journal of Sociology, 39, p. 377-407.

Szucs J. (1996). "The Three Historical Regions of Europe", In V. Gessner; A. Hoeland; C. Varga (eds.), European Legal Cultures, Aldershot: Dartmouth, p. 14-48.

Teubner G. (1997). "The Kings' Many Bodies: the Self-Destruction of Law's Hierarchy", Law and Society Review, v. 13, n.4, p. 763-787.

Tridimas T. (1991). "Judicial Review and Community Judicature: Towards a new European Constitutionalism?", Turku Law Review, 3, 1, p. 119-129. 
Vaininger H. (1911). Die Philosophie des Als Ob, Berlin (Italian translation by F. Voltaggio (1967). La filosofia del "come se". Sistema delle finzioni scientifiche, etico-pratiche e religiose del genere umano, Roma: Ubaldini).

Recebido para publicação em abril de 2011. 